\title{
Changes in short-lived climate pollutants during the COVID-19 pandemic in Tehran, Iran
}

\author{
Faezeh Borhani (D) Majid Shafiepour Motlagh • \\ Andreas Stohl (D) Yousef Rashidi (D. \\ Amir Houshang Ehsani
}

Received: 13 November 2020 / Accepted: 19 April 2021 / Published online: 8 May 2021

(C) The Author(s), under exclusive licence to Springer Nature Switzerland AG 2021

\begin{abstract}
This study investigates the changes of short-lived climate pollutants and other air pollutants during the COVID-19 pandemic in Tehran, Iran. Concentrations of air pollutants were obtained from 21 monitoring stations for the period from 5 January 2019 to 5 August 2019, representing normal conditions unaffected by COVID-19, and the period 5 January 2020 to 5 August 2020, i.e., during the COVID-19 crisis. We concentrated our analysis on three time windows (23 February 2020 to 15 March 2020, 18 March 2020 to 3 April 2020, and 5 April 2020 to 17 April 2020) during the lockdown when different sets of measures were taken to limit the
\end{abstract}

Highlights

- The changes of short-lived climate pollutants and air quality during the COVID-19 pandemic in Tehran were investigated.

- Concentrations of air pollutants in 2020, i.e., during the COVID-19 crisis, were compared to the 2019, representing period not affected by COVID-19 measures.

- The changes in air quality in 2020 compared to 2019 were quite modest, despite stringent COVID-19 lockdown measures in 2020.

F. Borhani $(\bowtie) \cdot$ M. Shafiepour Motlagh · A. H. Ehsani School of Environment, College of Engineering, University of Tehran, P.O. Box, 14155-6135 Tehran, Iran e-mail: fborhani78@ut.ac.ir

M. Shafiepour Motlagh e-mail: shafiepour@ut.ac.ir

A. H. Ehsani

e-mail: ehsani@ut.ac.ir spread of COVID-19. In comparison to the period not affected by COVID-19 measures, mean concentrations of pollutants were increased during the first lockdown period; when the number of COVID-19 patients increased sharply compared to the other periods, the mean surface concentrations of $\mathrm{NO}_{2}, \mathrm{SO}_{2}$, and $\mathrm{CO}$ were decreased and concentrations of other pollutants (i.e., $\mathrm{O}_{3}, \mathrm{PM}_{10}$, and $\mathrm{PM}_{2.5}$ ) were increased during the second lockdown period compared to the corresponding period in 2019. In the third period, the mean concentrations were decreased compared to the corresponding period in 2019. For the full period, decreases in mean concentrations of $\mathrm{O}_{3}, \mathrm{NO}_{2}$, $\mathrm{SO}_{2}, \mathrm{CO}$, and $\mathrm{PM}_{10}$ and increases in $\mathrm{PM}_{2.5}$ were observed during the COVID-19 crisis, compared to 2019. Overall, the strongest reductions, $12 \%$ and $6 \%$, respectively, were observed for $\mathrm{CO}$ and $\mathrm{NO}_{2}$, pointing to reduced emissions from traffic as a result of lockdown measures. The concentrations of other pollutants changed little, suggesting that the lockdown measures did not result in strong changes in the emissions from stationary sources.

\footnotetext{
A. Stohl

Department of Meteorology and Geophysics, University

of Vienna, Vienna, Austria

e-mail: andreas.stohl@univie.ac.at

Y. Rashidi

Environmental Sciences Research Institute, Shahid

Beheshti University, Tehran, Iran

e-mail: y_rashidi@sbu.ac.ir
} 
Keywords Air pollutants - Short-lived climate pollutants · COVID-19 pandemic · Air quality · Tehran

\section{Introduction}

The COVID-19 virus outbreak was first identified in December 2019 in Wuhan, China (WHO, 2020). On 19 February 2020, the first cases of pneumonia associated with COVID-19 (Coronavirus) were reported in Iran. Thereafter, the number of infected people increased quickly and the outbreak led to a national crisis. Iranian authorities shut down travel and transportation in and out of cities. They also established numerous quarantines and reduced local business travel, closed down colleges, universities, and schools in order to reduce the propagation of the disease.

Since restrictive measures were applied due to the Coronavirus outbreak, Tehran and some other cities have enjoyed cleaner air than under normal conditions. Medical doctors and some scientists argue that there may be a potential link between compromised lung capacity and long-term exposure to air pollution, which could make an individual exposed to high levels of air pollution more likely to develop a severe form of COVID-19 (Yongjian et al., 2020). The most important air pollutants in Tehran are nitrogen dioxide $\left(\mathrm{NO}_{2}\right)$, tropospheric ozone $\left(\mathrm{O}_{3}\right)$, carbon monoxide $(\mathrm{CO})$, sulfur dioxide $\left(\mathrm{SO}_{2}\right)$, and particulate matter $\left(\mathrm{PM}_{2.5}\right.$ and $\left.\mathrm{PM}_{10}\right) . \mathrm{PM}_{2.5}$ and $\mathrm{PM}_{10}$ are defined as the fractions of particles with aerodynamic diameters smaller than respectively 2.5 and $10 \mu \mathrm{m}$. An important component of $\mathrm{PM}_{2.5}$ is black carbon (BC), which is thought to be particularly harmful to human health (Sasser et al., 2012; EEA, 2013). The above mentioned pollutants are also short-lived climate pollutants (SLCPs), which are substantial contributors to climate change (e.g., Randall, 2008; Stohl et al., 2015; Retama et al., 2015; Kindbom et al., 2019). SLCPs contribute as much as $40 \%$ to climate change (IPCC, 2013). These pollutants, directly or by formation of secondary pollutants, have harmful influences on both air quality and climate (Stocker et al., 2013).

The effects of COVID-19 measures on air quality have already been studied for some regions. For example, for Spain, Ogen (2020) showed that out of 4443 fatality cases due to COVID-19, 3487 (78\%) were in five regions in central Spain. Additionally, the same five regions experienced large-scale subsidence, which prevented an efficient dispersion of air pollution. Menut et al. (2020) concluded that in Spain, the lockdown influence on atmospheric composition, particularly through reductions in traffic, has been significant for several short-lived atmospheric species, with a relatively small reduction in PM concentrations and a large reduction in the concentrations of $\mathrm{NO}_{2}$. Sicard et al. (2020) concluded that, during the lockdown in 2020, the mean daily concentrations of $\mathrm{O}_{3}$ at urban stations were higher by $14 \%$ in Rome, 2.4\% in Valencia, 24\% in Nice, 36\% in Wuhan, and $27 \%$ in Turin in comparison to the same period in 2017-2019. The increase in $\mathrm{O}_{3}$ concentrations in urban areas is mainly due to less $\mathrm{O}_{3}$ titration by $\mathrm{NO}$ as a result of the reduction in $\mathrm{NO}_{\mathrm{x}}$ emissions primarily in the form of NO (Sicard et al., 2020). A significant reduction of concentrations of pollutants in Quito during the 4 weeks of quarantine was reported by Zalakeviciute et al. (2020). Kumar (2020) investigated the pollutants and aerosols and compared them with the number of COVID-19 cases. The concentrations of aerosols and other pollutants were rapidly reduced from 25 March to 15 April during lockdown in India (Kumar, 2020).

Mannucci (2020) showed a remarkable decrease of $\mathrm{NO}_{2}$ in the north of Italy during the COVID-19 pandemic based on the ESA satellite Sentinel 5P records. Martelletti and Martelletti (2020) showed that Northern Italy, which was most strongly affected by COVID-19, also had high concentrations of particulate matter $\left(\mathrm{PM}_{10}\right.$ and $\left.\mathrm{PM}_{2.5}\right)$ that exceeded the legislative standards (i.e., $50 \mu \mathrm{g} \mathrm{m}^{-3}$ ) in February 2020. Sanita di Toppi et al. (2020) studied the possible relationship between air pollution, primarily airborne $\mathrm{PM}_{2.5-10}$, and the spread of COVID-19 in Northern Italy.

The objective of this study is to quantify the changes in air pollutant levels during the COVID-19 lockdown in Tehran. For this, we compare the concentrations of $\mathrm{O}_{3}, \mathrm{NO}_{2}, \mathrm{SO}_{2}, \mathrm{CO}, \mathrm{PM}_{10}$, and $\mathrm{PM}_{2.5}$ at 21 air quality monitoring stations in Tehran during the time periods from 5 January 2019 to 5 August 2019 (representing a baseline period not affected by COVID-19 measures) and 5 January 2020 to 5 August 2020 (i.e., during the COVID-19 crisis).

\section{Study area}

Tehran $\left(35^{\circ} 41^{\prime} \mathrm{N}\right.$ and $\left.51^{\circ} 23^{\prime} \mathrm{E}\right)$, the capital of Tehran Province and Iran (Fig. 1) and with a population of 8.7 


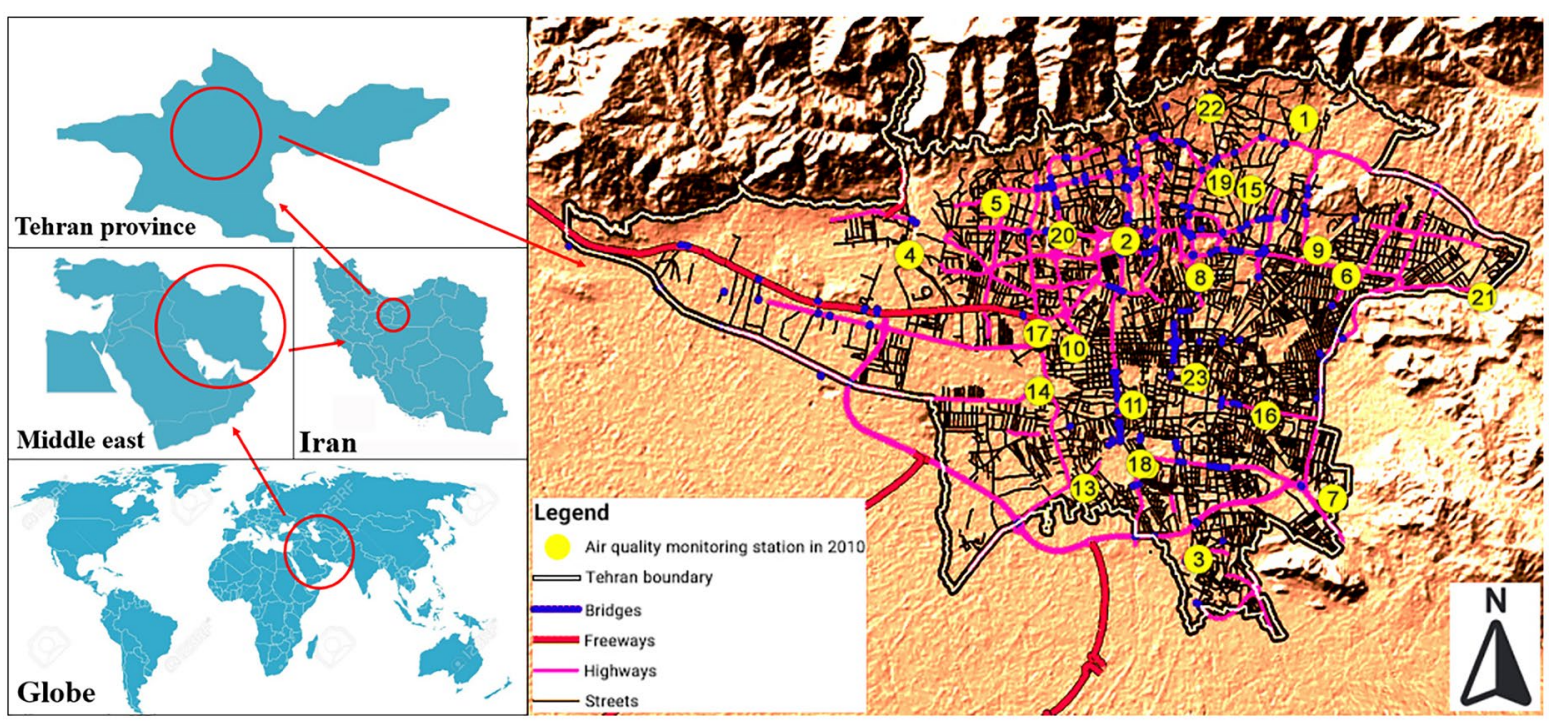

Fig. 1 The locations of the air quality monitoring stations in Tehran city; 1: Aqdasiyeh, 2: Sharif University, 3: Ray, 4: District 21, 5: Punak, 6: Golbarg, 7: Masoudieh, 8: Tarbiat Modares University, 9: District 4, 10: District 10, 11: Fath Sq.,

million people, the largest city in western Asia, covers an area of $751 \mathrm{~km}^{2}$. The city is limited by the Alborz Mountains in the north and the central desert in the south with approximate elevations of respectively $1980 \mathrm{~m}$ and 1117 $\mathrm{m}$ above sea level. The Alborz Mountains are acting as a barrier to the humid northerly air flow from the Caspian Sea. The topography also favors the formation of thermal inversions that trap polluted air in Tehran.

The annual minimum and maximum temperatures in Tehran are -15 and $43{ }^{\circ} \mathrm{C}$ and the average relative humidity is $40 \%$. The annual total rainfall in Tehran is $220 \mathrm{~mm}$. The metropolis of Tehran is divided into 22 municipal districts. Automobile and motorcycle emissions have a striking contribution to Tehran air pollution (Hassani \& Hosseini, 2016). In early 2018, over four million vehicles, including three million motorcycles, were registered in Tehran (MOHME, 2020); 400,000 of these vehicles were more than 15 years old and they accounted for about $32 \%$ of the capital's air pollution (MOHME, 2020).

\section{Measurement data and methods of analysis}

In this study, we compare measurement data obtained during the period of 5 January 2019 to 5 August 2019, which serves as a baseline not affected by
12: Setad Bohran, 13: District 19, 14: Shad Abad, 15: Darrous, 16: Mahallati, 17: Region 22, 18: District 16, 19: Sadr, 20: Rose Park, 21: Piroozi, 22: District 2, 23: District 11

the COVID-19 measures, and data obtained during the COVID-19 crisis period of 5 January 2020 to 5 August 2020. This allows to study the impact of the COVID-19 measures on the Tehran air quality, even though differences in the meteorological conditions between the 2 years may also have had an influence on air pollution levels. We used data from 21 monitoring stations (Fig. 1) that were obtained from the Tehran Department of Environment (DOE) and Tehran Air Quality Control Company (AQCC). The monitoring stations of Sharif University, Golbarg, Tarbiat Modares University, Setad Bohran, District 19, Mahallati, Region 22, District 16, Piroozi, and District 2 are urban stations. Also, traffic-related monitoring stations are Aqdasiyeh, Ray, District 21, Punak, Masoudieh, District 4, District 10, Fath Sq., Shad Abad, Darrous, Sadr, Rose Park, and District 11 (AQCC, 2020). The monitoring stations of Darrous and Rose Park were inactive during data recording of this study.

DOE and AQCC monitoring stations used UV absorption $\left(\mathrm{O}_{3} 42\right.$ Model $)$ to measure the $\mathrm{O}_{3}$ concentration according to ISO 13964, 2008/50/EC, en 14625, EN $15267.40 \mathrm{cfr}$ part 53, and $40 \mathrm{cfr}$ part 58. All stations used chemiluminescent sensors (Model APNA-370 of Horiba, Japan; AC 32 M of Environment SA, France, and EC 9841 of Ecotech, Australia) to measure $\mathrm{NO}_{2}$. 
UV Fluorescent Sensor (LSI-Babuc/A Made by LSI Company in Italy) were used to record $\mathrm{SO}_{2}$ concentrations. Monitoring stations used non-dispersive infrared spectrometry (NDIR) analyzers to measure the CO concentration. Analysis of inorganic gaseous pollutants (i.e., $\mathrm{NO}_{2}, \mathrm{SO}_{2}$, and $\mathrm{CO}$ ) performed according to the European Air Quality Directive 2008/50/EC and recent revision 2015/1480/EC. The measuring method for $\mathrm{PM}_{10}$ and $\mathrm{PM}_{2.5}$ concentrations was tapered-element oscillating microbalance, TEOM (Dust Trak TSI, Model Echo Pm, Made by TCI Tecora Company in Italy), according to the AAQ NEPM standard. Recording system follows QA/QC (i.e., quality assurance/quality control) procedures that, under ideal circumstances, ensure the instruments are calibrated and checked every 2 weeks.
The concentrations of $\mathrm{O}_{3}, \mathrm{NO}_{2}, \mathrm{SO}_{2}, \mathrm{CO}, \mathrm{PM}_{10}$, and $\mathrm{PM}_{2.5}$ were measured hourly. The average of hourly values from all 21 monitoring stations was taken as representative for the conditions in Tehran as a whole, and then hourly values were averaged to daily values. The pollution data are validated for each monitoring station during the study period. Zero and negative values and the data that were very inconsistent with other data due to some local phenomena such as fire were removed from the database. Stations with more than $75 \%$ available hourly concentrations data were considered valid. Accordingly, all 21 stations were valid for data processing. To determine the statistical significance, one sample test was used. The statistical parameters of the database utilized in this study are presented in Table 1 .

Table 1 Statistical analysis of database of pollutants and AQI

\begin{tabular}{|c|c|c|c|c|c|c|c|c|c|}
\hline \multirow[t]{2}{*}{ Pollutants \& AQI } & \multirow[t]{2}{*}{ Dataset } & \multicolumn{4}{|c|}{2019 (Normal conditions) } & \multicolumn{4}{|c|}{2020 (During COVID-19 pandemic) } \\
\hline & & Max & Min & Mean & SD & Max & Min & Mean & SD \\
\hline \multirow[t]{4}{*}{$\mathrm{O}_{3}$} & All data & 46.70 & 6.50 & 25.13 & 9.38 & 44.12 & 4.47 & 24.55 & 10.33 \\
\hline & First period & 23.67 & 10.93 & 17.63 & 2.75 & 23.95 & 9.16 & 16.98 & 3.68 \\
\hline & Second period & 33.07 & 14.33 & 24.30 & 4.81 & 31.84 & 20.47 & 24.75 & 3.06 \\
\hline & Third period & 30.67 & 18.20 & 24.26 & 3.43 & 27.33 & 13.26 & 21.79 & 5.00 \\
\hline \multirow[t]{4}{*}{$\mathrm{NO}_{2}$} & All data & 76.17 & 33.13 & 47.59 & 7.35 & 72.06 & 23.89 & 44.86 & 9.44 \\
\hline & First period & 53.38 & 39.94 & 47.99 & 3.83 & 65.11 & 37.94 & 52.01 & 7.83 \\
\hline & Second period & 46.40 & 33.13 & 39.47 & 2.98 & 34.78 & 23.89 & 29.75 & 3.09 \\
\hline & Third period & 46.13 & 40.27 & 42.70 & 1.87 & 45.55 & 32.22 & 39.20 & 4.34 \\
\hline \multirow[t]{4}{*}{$\mathrm{SO}_{2}$} & All data & 10.06 & 2.40 & 4.80 & 1.50 & 10.61 & 2.56 & 4.79 & 1.59 \\
\hline & First period & 9.56 & 3.44 & 5.52 & 1.58 & 7.67 & 3.94 & 5.79 & 1.14 \\
\hline & Second period & 5.19 & 2.40 & 3.45 & 0.71 & 4.56 & 2.56 & 3.17 & 0.50 \\
\hline & Third period & 5.60 & 2.53 & 3.78 & 0.77 & 5.17 & 2.67 & 3.53 & 0.64 \\
\hline \multirow[t]{4}{*}{$\mathrm{CO}$} & All data & 3.22 & 0.87 & 1.57 & 0.41 & 2.56 & 0.75 & 1.38 & 0.34 \\
\hline & First period & 2.06 & 1.29 & 1.61 & 0.22 & 2.56 & 0.94 & 1.61 & 0.38 \\
\hline & Second period & 1.76 & 0.88 & 1.17 & 0.22 & 1.31 & 0.75 & 0.98 & 0.13 \\
\hline & Third period & 1.59 & 1.06 & 1.32 & 0.15 & 1.44 & 0.94 & 1.17 & 0.19 \\
\hline \multirow[t]{4}{*}{$\mathrm{PM}_{10}$} & All data & 162.44 & 25.44 & 66.77 & 23.56 & 114.00 & 18.63 & 63.42 & 18.66 \\
\hline & First period & 75.81 & 41.56 & 55.97 & 10.38 & 101.12 & 35.71 & 65.07 & 15.92 \\
\hline & Second period & 53.13 & 25.43 & 33.53 & 7.55 & 61.00 & 18.63 & 35.89 & 11.33 \\
\hline & Third period & 71.69 & 39.50 & 50.75 & 12.37 & 47.75 & 22.25 & 37.14 & 7.93 \\
\hline \multirow[t]{4}{*}{$\mathrm{PM}_{2.5}$} & All data & 57.33 & 10.27 & 24.71 & 8.20 & 65.25 & 9.38 & 25.69 & 8.95 \\
\hline & First period & 35.53 & 15.47 & 22.35 & 5.35 & 65.25 & 14.31 & 29.64 & 11.99 \\
\hline & Second period & 25.40 & 10.27 & 14.88 & 4.05 & 23.38 & 9.38 & 15.77 & 3.62 \\
\hline & Third period & 22.60 & 15.67 & 18.99 & 2.35 & 26.00 & 12.50 & 18.91 & 3.88 \\
\hline \multirow[t]{4}{*}{ AQI } & All data & 160.00 & 32.00 & 75.85 & 26.58 & 161.00 & 30.00 & 83.49 & 26.19 \\
\hline & First period & 93.00 & 38.00 & 67.38 & 15.10 & 136.00 & 30.00 & 86.00 & 25.82 \\
\hline & Second period & 98.00 & 33.00 & 49.47 & 17.89 & 80.00 & 39.00 & 59.35 & 11.31 \\
\hline & Third period & 59.00 & 35.00 & 46.23 & 7.35 & 84.00 & 39.00 & 56.69 & 13.78 \\
\hline
\end{tabular}

Max maximum, Min minimum, $S D$ standard deviation 
Table 2 The $P$-value for pollutants and AQI

${ }^{*} P<0.05$

\begin{tabular}{llllllll}
\hline Dataset & $\mathrm{O}_{3}$ & $\mathrm{NO}_{2}$ & $\mathrm{SO}_{2}$ & $\mathrm{CO}$ & $\mathrm{PM}_{10}$ & $\mathrm{PM}_{2.5}$ & $\mathrm{AQI}$ \\
\hline All data & 0.539 & $0.0009^{*}$ & 0.919 & $0.0000^{*}$ & 0.103 & 0.241 & $0.002^{*}$ \\
First period & 0.492 & $0.030^{*}$ & 0.495 & 0.987 & $0.024^{*}$ & $0.010^{*}$ & $0.004^{*}$ \\
Second period & 0.750 & $0.0000^{*}$ & 0.194 & $0.005^{*}$ & 0.479 & 0.504 & 0.064 \\
Third period & 0.156 & $0.016^{*}$ & 0.369 & $0.036^{*}$ & $0.003^{*}$ & 0.949 & $0.026^{*}$ \\
\hline
\end{tabular}

Student's $t$-test (Ju et al., 2020) was used to determine whether the differences of the mean concentrations in 2019 and 2020 were significant. Table 2 presents the $P$-value for each pollutant and AQI. In the current research, the $P$-value $<0.05$ was considered as statistically significant.

As an overall measure of air quality, we calculated a so-called air quality index (AQI) (US EPA, 2011), which combines information about several pollutants (i.e., $\mathrm{O}_{3}, \mathrm{NO}_{2}, \mathrm{SO}_{2}, \mathrm{CO}, \mathrm{PM}_{10}$, and $\mathrm{PM}_{2.5}$ ). The AQI calculation was conducted in two steps: (1) the maximum values of $1-$ and $8-\mathrm{h} \mathrm{O}_{3}$, maximum $1-\mathrm{h}$ $\mathrm{NO}_{2}$, maximum values of $8-\mathrm{h} \mathrm{CO}$, and maximum $24 \mathrm{~h}$ and maximum values for $\mathrm{PM}_{10}, \mathrm{PM}_{2.5}$, and $\mathrm{SO}_{2}$ were extracted, and (2) the AQI was calculated as following:

$\rho_{\mathrm{P}}=\frac{\rho_{\mathrm{HI}}-\rho_{\mathrm{LO}}}{B P_{\mathrm{HI}}-B P_{\mathrm{LO}}} \times\left(C_{\mathrm{P}}-B P_{\mathrm{LO}}\right)+\rho_{\mathrm{LO}}$

$A Q I=\max \left(\rho_{\mathrm{O}_{3}}, \rho_{\mathrm{NO}_{2}}, \rho_{\mathrm{SO}_{2}}, \rho_{\mathrm{CO}}, \rho_{\mathrm{PM}_{10}}, \rho_{\mathrm{PM}_{2.5}}\right)$

where $\rho_{\mathrm{P}}$ is the index for pollutant $\mathrm{p}$, the $C_{\mathrm{P}}$ is the rounded concentration of pollutant $\mathrm{p}, B P_{\mathrm{HI}}$ is the concentrations of pollutants that is higher than or equal to $C_{\mathrm{P}}, B P_{\mathrm{LO}}$ is the concentrations of pollutants that is lower than or equal to $C_{\mathrm{P}}, \rho_{\mathrm{HI}}$ is the AQI value corresponding to $B P_{\mathrm{HI}}$, and $\rho_{\mathrm{LO}}$ is the AQI value corresponding to $B P_{\mathrm{LO}}$.

Table 3 Standard levels for air pollutants (WHO, 2003; US EPA, 2011)

\begin{tabular}{lll}
\hline Pollutant & Averaging time & Level \\
\hline $\mathrm{CO}$ & $8 \mathrm{~h}$ & $<9.4 \mathrm{ppm}$ \\
$\mathrm{NO}_{2}$ & $1 \mathrm{~h}$ & $<100 \mathrm{ppb}$ \\
$\mathrm{O}_{3}$ & $8 \mathrm{~h}$ & $<70 \mathrm{ppb}$ \\
$\mathrm{PM}_{2.5}$ & $24 \mathrm{~h}$ & $<35 \mu \mathrm{g} / \mathrm{m}^{3}$ \\
$\mathrm{PM}_{10}$ & $24 \mathrm{~h}$ & $<150 \mu \mathrm{g} / \mathrm{m}^{3}$ \\
$\mathrm{SO}_{2}$ & $24 \mathrm{~h}$ & $<140 \mathrm{ppb}$ \\
\hline
\end{tabular}

The AQI (developed by United States Environmental Protection Agency, US EPA, 2011) ranges from 0 to 500 and is an indicator of the overall air quality. Values of 0-50 correspond to good air quality, 51-100 to moderate, 101-150 to unhealthy for sensitive groups, 151-200 to unhealthy, 201-300 to very unhealthy, and 301-500 to hazardous conditions. Standard levels for air pollutants (WHO, 2003; US EPA, 2011) are presented in Table 3.

\section{Results and discussion}

The daily mean surface concentrations of $\mathrm{O}_{3}, \mathrm{NO}_{2}$, $\mathrm{SO}_{2}, \mathrm{CO}, \mathrm{PM}_{10}$, and $\mathrm{PM}_{2.5}$, averaged over the 21 air quality monitoring stations, are shown in Fig. 2a-f. Compared to our 2019 reference period that was not affected by COVID-19 measures, the mean concentrations of $\mathrm{O}_{3}, \mathrm{NO}_{2}, \mathrm{SO}_{2}, \mathrm{CO}$, and $\mathrm{PM}_{10}$ in 2020 were lower by about $2.3 \%, 6 \%, 0.3 \%, 12 \%$, and $5 \%$, respectively, and the mean concentration of $\mathrm{PM}_{2.5}$ was higher by about $4 \%$ for the whole period considered (Fig. 2a-f). Carbon monoxide, which is strongly influenced by traffic sources, showed the strongest reduction compared to 2019, from 1.57 ppm in 2019 to $1.38 \mathrm{ppm}$ in 2020. Both values are substantially below Iran's clean air quality standard (i.e., 9 ppm) (Fig. 2d). The $t$-test results shown in Table 2 indicate that there was no significant difference between the mean concentration of $\mathrm{O}_{3}, \mathrm{SO}_{2}$, and $\mathrm{PM}_{2.5}$ in 2019 and 2020 (95\% confidence interval), whereas a significant difference was observed between the mean concentrations of $\mathrm{NO}_{2}$ and $\mathrm{CO}$ and also of the AQI level $(P$-value $<0.05)$.

The maximum AQI value, 161, in Tehran during the COVID-19 crisis was recorded on July 19, 2020 (Fig. 2g), due to high ozone concentrations. The mean AQI was higher by about $10 \%$ from January 5, 2020, to August 5, 2020, compared to the corresponding period in 2019 (Table 1). The air quality in Tehran during the study period (January 5, 2020, to August 
Fig. 2 Time-series of daily mean surface concentrations averaged over 21 air quality monitoring stations for $\mathbf{a} \mathrm{O}_{3}, \mathbf{b} \mathrm{NO}_{2}, \mathbf{c ~ S O}$, d $\mathrm{CO}$, e $\mathrm{PM}_{10}$, f $\mathrm{PM}_{2.5}$, g AQI (FT, first period; SP, second period; TP, third period)
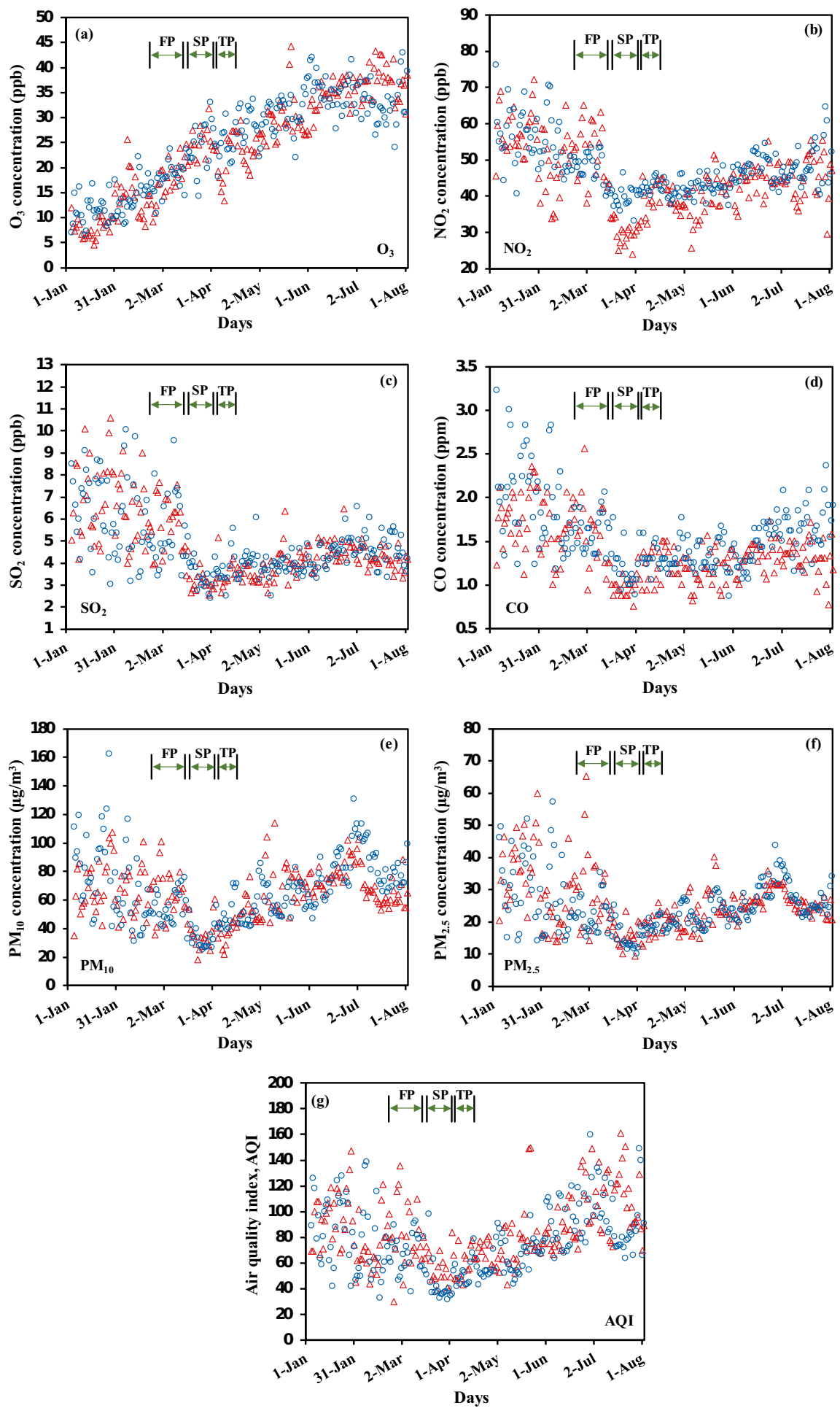

$\Delta 2020$ (during Covid-19 pandemic) $\circ 2019$ (normal conditions) 
5, 2020) was good, moderate, unhealthy for sensitive groups, and unhealthy, respectively, in 19, 143, 50, and 2 days. The corresponding values in 2019 were $36,140,37$, and 1 days, respectively, reflecting a small shift to more unhealthy conditions in 2020 .

The concentration of ozone at the beginning of 2020 was lower than that of the previous year. However, Fig. 2 shows that the ozone concentration gradually increased during the season, as conditions became more conducive to ozone formation (higher temperature and more sunlight). As a result, 2020 ozone concentration exceeded the 2019 values and eventually increased during the study period.

To clarify the effects of the measures to prevent the propagation of COVID-19 in Tehran, three time windows during the whole study period were examined.

First period: from 23 February 2020 to 15 March 2020

Although the Iranian government officially closed schools, universities, and banned religious and cultural gatherings in this period to contain the spread of COVID-19, huge crowds of people were still shopping in Tehran Grand Bazaar. Moreover, the streets leading to the bazaar were full of cars as Iranians were getting prepared for Nowruz, the New Year, which started on March 20, 2020. Traffic jams were clogging Tehran's streets as people were departing the city for a vacation. These worrying behaviors revealed that most Iranians were refusing to take social distancing seriously, squandering any chance to contain the outbreak. In this first period, during the COVID-19 pandemic, the mean concentration of $\mathrm{O}_{3}$ decreased by $4 \%$ and the mean concentration of $\mathrm{NO}_{2}$, $\mathrm{SO}_{2}, \mathrm{PM}_{10}$, and $\mathrm{PM}_{2.5}$ increased by $8 \%, 5 \%, 14 \%$, and $25 \%$, respectively, compared to the baseline period not affected by COVID-19 measures (Fig. 3a-f).

High concentrations of SLCPs in the first period can be attributed to the thermal inversion that occurs during the winter and prevents the dilution of pollutants. Available studies suggest that exposure to $\mathrm{SO}_{2}$, $\mathrm{NO}_{2}$, and $\mathrm{CO}$ is detrimental to health and increases the risk of respiratory diseases (e.g., Chen et al., 2007). The $t$-test results indicated that there was no significant difference between the mean concentration of $\mathrm{O}_{3}, \mathrm{SO}_{2}$, and $\mathrm{CO}$ in 2019 and $2020(95 \%$ confidence interval) during the first period, whereas a significant difference was observed between the mean concentration of $\mathrm{NO}_{2}$ and $\mathrm{PM}_{10}$, and $\mathrm{PM}_{2.5}$ as well as AQI level $(P$-value $<0.05)$ (Table 2$)$.

When a person infected with the Coronavirus breathes vigorously, sneezes, coughs, and speaks loudly, the virus will be excreted from the body (Zoran et al., 2020). It may be dissolved in the aerosol and turns into bio-aerosols (Zoran et al., 2020). Atmospheric particulate matter sized 1-5 $\mu \mathrm{m}$ generally remains in the air and larger particles land on surfaces. Aerosols can travel hundreds of meters or more, whereas droplets spread about 1-2 m from the source of infection. Similar studies have shown that short-term exposure to air pollutants (i.e., $\mathrm{O}_{3}$, $\mathrm{NO}_{2}, \mathrm{SO}_{2}, \mathrm{CO}, \mathrm{PM}_{2.5}$, and $\mathrm{PM}_{10}$ ) is associated with increased risk of COVID-19 infection (Zou et al., 2020; Wu et al., 2020).

Second period: from 18 March 2020 to 3 April 2020

In the second period, the Iranian government ordered the bazaars and shopping centers across the country to be closed for the whole 17-day holiday. Only pharmacies and supermarkets were kept open. However, ignoring the recommendations of the health officials, some Iranians took trips during Nowruz holidays. During this period, the mean concentration of $\mathrm{O}_{3}$ in Tehran increased (from 2019 to 2020) from 24.3 to $24.7 \mathrm{ppb}$ $(<70 \mathrm{ppb}$ ) (Fig. 4a), while the mean concentrations of $\mathrm{SO}_{2}, \mathrm{NO}_{2}$, and $\mathrm{CO}$ in Tehran decreased from 3.45 to $3.17 \mathrm{ppb}(<140 \mathrm{ppb})$, from 39.5 to $29.7 \mathrm{ppb}(<100$ $\mathrm{ppb}$ ), and from 1.17 to $0.98 \mathrm{ppm}(<9.4 \mathrm{ppm}$ ) (Fig. $4 \mathrm{~b}$, c, and d), respectively. This can be attributed to the decrease in urban transport and economic activity during lockdown and Nowruz holidays. These changes are relatively small, except for $\mathrm{NO}_{2}$ that was reduced quite substantially (by 25\%). These results are consistent with the finding of Gautam (2020) who found that the $\mathrm{NO}_{2}$ concentrations were substantially reduced in Asian and European countries after going into COVID19 lockdown. The $\mathrm{NO}_{2}$ reduction is likely mostly due to the reduction in traffic, which is an important source of $\mathrm{NO}_{\mathrm{x}}$. Cameletti (2020) also showed that the air quality considerably changed during the intervention only at a single $\mathrm{NO}_{2}$ station located in a heavy traffic zone. 

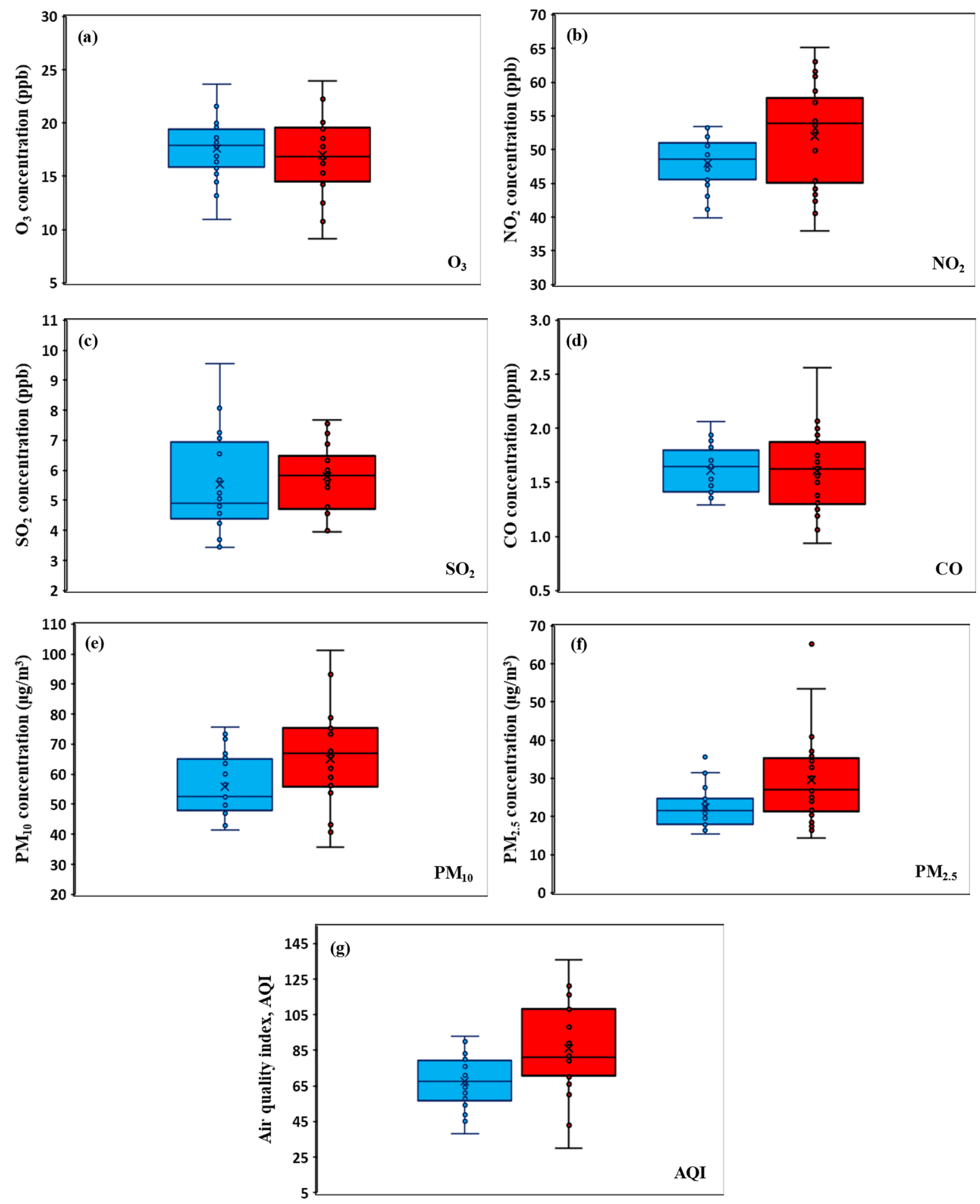

Fig. 3 Box-and-whiskers plots of the frequency distributions of daily pollutant concentrations in Tehran (average of 21 stations within the city) for 2019 and 2020 during the period 23 February to $15 \mathrm{March}_{\text {for }} \mathbf{a} \mathrm{O}_{3}, \mathbf{b} \mathrm{NO}_{2}, \mathbf{c} \mathrm{SO}_{2}, \mathbf{d ~ C O}, \mathbf{e ~ P M} \mathrm{PM}_{10}$, f PM 2.5 , g AQI 

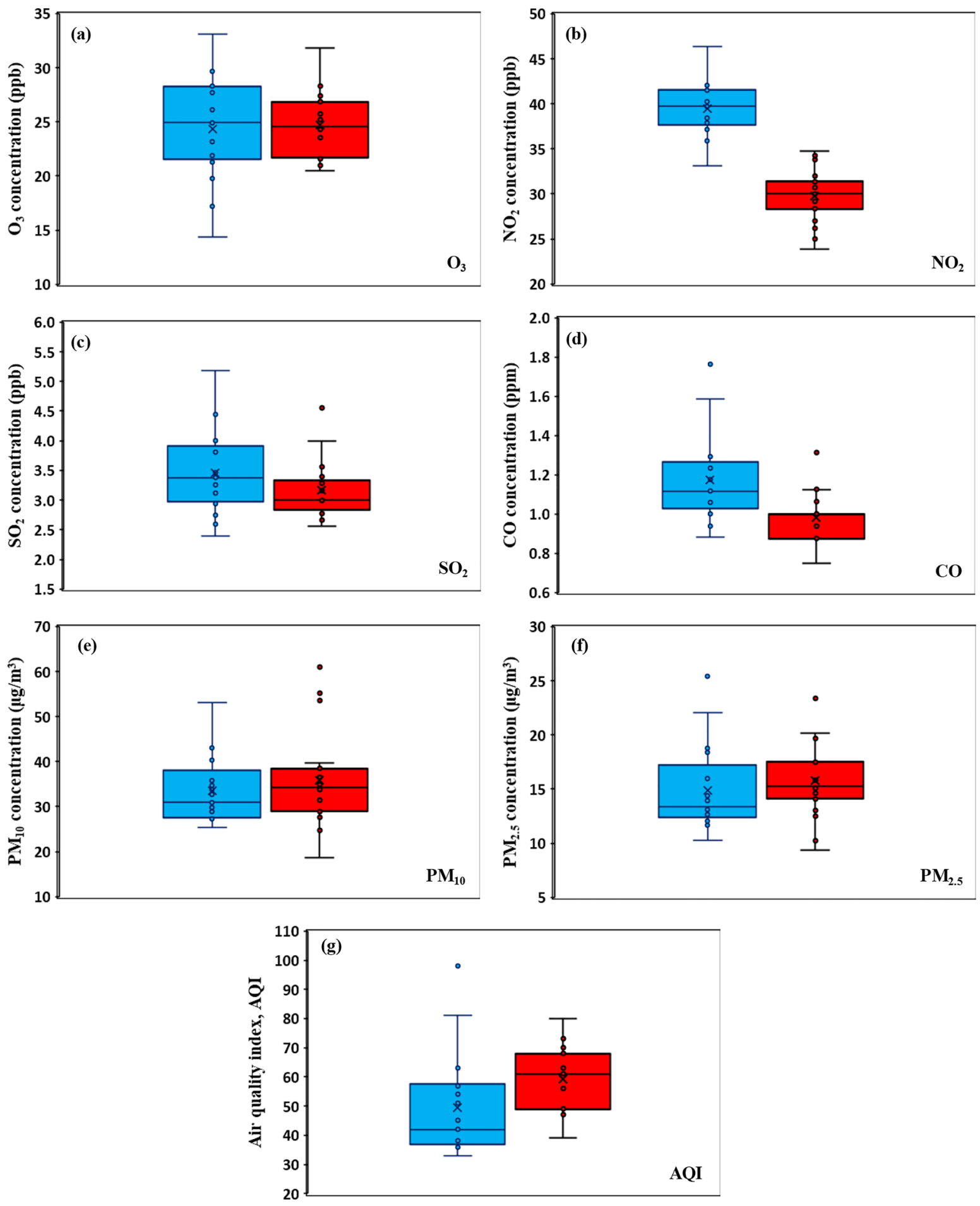

$\square 2019$ (normal conditions)

2020 (during COVID-19 pandemic)

Fig. 4 Box-and-whiskers plots of the frequency distributions of daily pollutant concentrations in Tehran (average of 21 stations within the city) for 2019 and 2020 during the period 18 March to 3 April for a $\mathrm{O}_{3}, \mathbf{b ~} \mathrm{NO}_{2}, \mathbf{c ~} \mathrm{SO}_{2}$, d CO, e PM 10 , f PM 2.5 , g AQI 

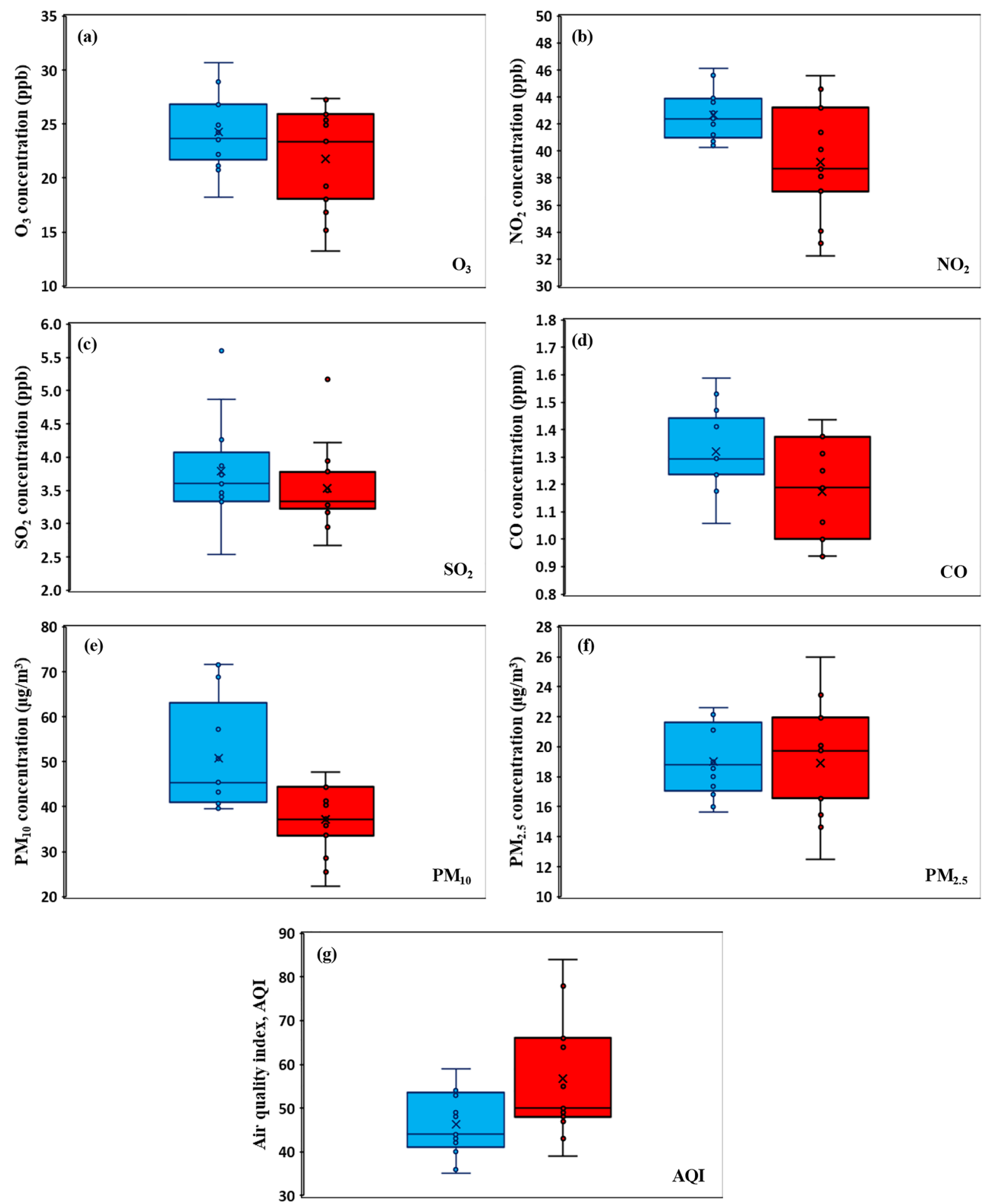

$\square 2019$ (normal conditions)

2020 (during COVID-19 pandemic)

Fig. 5 Box-and-whiskers plots of the frequency distributions of daily pollutant concentrations in Tehran (average of 21 stations within the city) for 2019 and 2020 during the period 5 April to 17 April for a $\mathrm{O}_{3}, \mathbf{b} \mathrm{NO}_{2}, \mathbf{c} \mathrm{SO}_{2}$, d CO, e PM 10 , f PM 2.5 , g AQI 
The mean concentration of $\mathrm{PM}_{2.5}$ and $\mathrm{PM}_{10}$ increased from 14.9 and $33.5 \mu \mathrm{g} \mathrm{m}^{-3}$ to $15.8\left(<35 \mu \mathrm{g} \mathrm{m}^{-3}\right)$ and $35.9 \mu \mathrm{g} \mathrm{m}^{-3}\left(<150 \mu \mathrm{g} \mathrm{m}^{-3}\right)$ during Nowruz holidays and the Coronavirus outbreak compared to the previous year in the second period (Fig. 4e, f). As presented in Table 2, the $t$-test results related to the second period indicated a significant difference between the mean concentration of $\mathrm{NO}_{2}$ and $\mathrm{CO}$ as well as AQI level ( $P$-value $<0.05$ ), although no significant difference was found between the mean concentration of $\mathrm{O}_{3}, \mathrm{SO}_{2}, \mathrm{PM}_{10}$, and $\mathrm{PM}_{2.5}$ in 2019 and 2020 (95\% confidence interval).

Unfavorable meteorological conditions hindered the dispersion of pollutants during study period. Stationary sources can be considered one of the reasons for the increase in suspended particles. In the second period of the COVID-19 crisis, the mean value of AQI increased by about $20 \%$, compared to the corresponding period in 2019 (Fig. 4g and Table 1). In this period, due to the low vehicle traffic in Tehran, the blowing wind from the south of Tehran was identified as the only factor increasing the index. This suggests that the pollution caused by industries and stationary sources located in the south of Tehran caused the increases in the concentration of pollutants in the second period.

\section{Third period: from 5 April 2020 to 17 April 2020}

In the third period, offices and manufacturing and service businesses reopened extensively after the Coronavirus outbreak. However, because of meteorological conditions, during third period, the mean concentration of $\mathrm{O}_{3}, \mathrm{NO}_{2}, \mathrm{SO}_{2}, \mathrm{CO}, \mathrm{PM}_{10}$, and $\mathrm{PM}_{2.5}$ decreased by about $10 \%, 8 \%, 7 \%, 11 \%, 27 \%$, and $1 \%$, respectively, compared to the corresponding period in 2019 (Fig. 5a-f). On April 10, 2020, $\mathrm{O}_{3}$ concentration decreased from 26.93 to $13.26 \mathrm{ppb}(<70 \mathrm{ppb})$. Due to the reduced vehicle traffic on April 10, 2020, and the establishment of favorable weather conditions, air quality was probably in a clean and healthy range. The wind speed reduction and the vehicle traffic increase after April 11, 2020, relatively increased the concentration of pollutants and, consequently, the establishment of unfavorable conditions could not be unexpected. The $t$-test results indicated that although there was no significant difference between the mean concentration of $\mathrm{O}_{3}, \mathrm{SO}_{2}$, and $\mathrm{CO}$ in 2019 and 2020 (95\% confidence interval) in the third period, there was a significant difference between the mean concentration of $\mathrm{NO}_{2}$ and $\mathrm{PM}_{10}$, and $\mathrm{PM}_{2.5}$ as well as the AQI level $(P$-value $<0.05)$ (Table 2$)$.

\section{Conclusions}

In this study, the concentrations of air pollutants in Tehran city were obtained from 21 monitoring stations for the period from January 5, 2019, to August 5,2019 , representing a period unaffected by COVID19 measures, and from January 5, 2020, to August 5, 2020, which was during the COVID-19 pandemic. Analyses were performed for three time windows (February 23, 2020, to March 15, 2020; March 18, 2020, to April 3, 2020, and April 5, 2020, to April 17, 2020) during lockdown when different sets of measures were taken to prevent the spread of COVID-19. During the first lockdown period, in comparison to the period not affected by COVID-19 measures, the mean concentration of $\mathrm{NO}_{2}, \mathrm{PM}_{10}$, and $\mathrm{PM}_{2.5}$ increased. The mean surface concentration of $\mathrm{NO}_{2}, \mathrm{SO}_{2}$, and $\mathrm{CO}$ decreased and that of $\mathrm{PM}_{10}$ and $\mathrm{PM}_{2.5}$ increased during the second lockdown period compared to the corresponding period in 2019. In the third period, the mean concentration of $\mathrm{O}_{3}, \mathrm{NO}_{2}, \mathrm{SO}_{2}, \mathrm{CO}$, and $\mathrm{PM}_{10}$ decreased compared to the corresponding period in 2019. In the entire period, the mean concentration of CO reduced by about $12 \%$ during the COVID-19 crisis, compared to 2019. Moreover, the concentration of $\mathrm{NO}_{2}$ decreased by $6 \%$ during the full period.

In summary, the changes in air quality in 2020 compared to 2019 were quite modest, despite stringent COVID-19 lockdown measures in 2020. There were clear reductions in average $\mathrm{CO}$ and $\mathrm{NO}_{2}$ concentrations in Tehran, mainly related to reductions in traffic emissions. On the other hand, the concentrations of ozone within the city were not reduced, and there were days with quite high pollutant levels overall, resulting in higher average values of the air quality index (AQI), corresponding to worse air quality, in 2020 than in 2019.

Acknowledgements Special thanks are extended to Tehran Air Quality Control Company (AQCC), Department of Environment (DOE), and Ministry of Health \& Medical Education (MOHME) for efficient help in providing the database of this study.

Data availability The database analyzed during the present study are available from the corresponding author on reasonable request.

\section{Declarations}

Competing interests The authors declare no competing interests. 


\section{References}

Cameletti, M. (2020). The effect of Corona virus lockdown on air pollution: Evidence from the city of Brescia in Lombardia region (Italy). Atmospheric Environment, 239, 117794.

Chen, T. M., Kuschner, W. G., Gokhale, J., \& Shofer, S. (2007). Outdoor air pollution: Nitrogen dioxide, sulfur dioxide, and carbon monoxide health effects. The American Journal of the Medical Sciences, 333(4), 249-256.

EEA, European Environment Agency. (2013). Air quality in Europe-2013 report, EEA Report No. 9/2013.

Gautam, S. (2020). COVID-19: Air pollution remains low as people stay at home. Air Quality, Atmosphere, \& Health, $13,853-857$.

Hassani, A., \& Hosseini, V. (2016). An assessment of gasoline motorcycle emissions performance and understanding their contribution to Tehran air pollution. Transportation Research Part D: Transport and Environment, 47, 1-12.

IPCC, Intergovernmental Panel on Climate Change. (2013). The physical science basis. A UN Committee's Assessment Report.

Ju, M. J., Oh, J., \& Choi, Y. H. (2020). Changes in air pollution levels after COVID-19 outbreak in Korea. Science of The Total Environment, 750, 141521.

Kindbom, K., Nielsen, O. K., Saarinen, K., Jonsson, K., Aasestad, K. (2019). Policy brief-emissions of short-lived climate pollutants (SLCP): Emission factors, scenarios and reduction potentials. Nordic Council of Ministers.

Kumar, S. (2020). Effect of meteorological parameters on spread of COVID-19 in India and air quality during lockdown. Science of The Total Environment, 745, 141021.

Mannucci, P. M. (2020). Traffic-related air pollution and the coronavirus pandemia: Shadows and lights. European Journal of Preventive Cardiology. https://doi.org/10. 1177\%2F2047487320928451

Martelletti, L., \& Martelletti, P. (2020). Air pollution and the novel Covid-19 disease: A putative disease risk factor. $S N$ Comprehensive Clinical Medicine, 2, 383-387.

Menut, L., Bessagnet, B., Siour, G., Mailler, S., Pennel, R., \& Cholakian, A. (2020). Impact of lockdown measures to combat Covid-19 on air quality over western Europe. Science of The Total Environment, 741, 140426.

Ministry of Health \& Medical Education, MOHME. (2020). Coronavirus epidemic in Iran.

Ogen, Y. (2020). Assessing nitrogen dioxide $\left(\mathrm{NO}_{2}\right)$ levels as a contributing factor to the coronavirus (COVID-19) fatality rate. Science of The Total Environment, 726, 138605.

Randall, S. (2008). Baseline assessment of short-lived climate pollutants in Bangladesh, In: Proceedings of 3rd International Conference on Environmental Aspects of Bangladesh, (p. 33).

Retama, A., Baumgardner, D., Raga, G. B., McMeeking, G. R., \& Walker, J. W. (2015). Seasonal trends in black carbon properties and co-pollutants in Mexico City. Atmospheric Chemistry \& Physics Discussions, 15(8), 12539-12582.

Sanita di Toppi, L., Sanita di Toppi, L., \& Bellini, E. (2020). Novel coronavirus: How atmospheric particulate affects our environment and health. Challenges, 11(1), 6 .
Sasser, E., Hemby, J., Adler, K., Anenberg, S., Bailey, C., Brockman, L., Chappell, L., DeAngelo, B., Damberg, R., Dawson, J., Frank, N. (2012). Report to congress on black carbon. Department of the Interior, Environment, and Related Agencies.

Sicard, P., De Marco, A., Agathokleous, E., Feng, Z., Xu, X., Paoletti, E., Rodriguez, J. J. D., \& Calatayud, V. (2020). Amplified ozone pollution in cities during the COVID19 lockdown. Science of The Total Environment, 735, 139542.

Stocker, T. F., Qin, D., Plattner, G. K., Tignor, M., Allen, S. K., Boschung, J., Nauels, A., Xia, Y., Bex, V., Midgley, P. M. (2013). Contribution of working group I to the fifth assessment report of the intergovernmental panel on climate change. Climate Change, 953-1028.

Stohl, A., Aamaas, B., Amann, M., Baker, L., Bellouin, N., Berntsen, T. K., Boucher, O., Cherian, R., Collins, W., Daskalakis, N., \& Dusinska, M. (2015). Evaluating the climate and air quality impacts of short-lived pollutants. Atmospheric Chemistry and Physics, 15(18), 10529-10566.

Tehran Air Quality Control Company, AQCC. (2020). http://air. tehran.ir/

US EPA, Air Quality Index, AQI. (2011). A guide to air quality and your health. 9 December 2011. Retrieved 8 August 2012.

WHO, World Health Organization. (2003). Health aspects of air pollution with particulate matter, ozone and nitrogen dioxide: Report on a WHO working group, Bonn, Germany 13-15 January 2003, No. EUR/03/5042688.

WHO, World Health Organization. (2020). Coronavirus disease 2019 (COVID-19) Situation Report.

Wu, X., Nethery, R. C., Sabath, B. M., Braun, D., Dominici, F. (2020). Exposure to air pollution and COVID-19 mortality in the United States. medRxiv. https://doi.org/10.1101/2020. 04.05.20054502

Yongjian, Z., Jingu, X., Fengming, H., \& Liqing, C. (2020). Association between short-term exposure to air pollution and COVID-19 infection: Evidence from China. Science of the Total Environment, 727, 138704.

Zalakeviciute, R., Vasquez, R., Bayas, D., Buenano, A., Mejia, D., Zegarra, R., Diaz, A., \& Lamb, B. (2020). Drastic improvements in air quality in Ecuador during the COVID-19 outbreak. Aerosol and Air Quality Research, 20, 1783-1792.

Zoran, M. A., Savastru, R. S., Savastru, D. M., Tautan, M. N. (2020). Assessing the relationship between surface levels of PM2.5 and PM10 particulate matter impact on COVID-19 in Milan, Italy. Science of The Total Environment, 738, 139825.

Zou, L., Ruan, F., Huang, M., Liang, L., Huang, H., Hong, Z., Yu, J., Kang, M., Song, Y., Xia, J., \& Guo, Q. (2020). SARS-CoV-2 viral load in upper respiratory specimens of infected patients. New England Journal of Medicine, 382(12), 1177-1179.

Publisher's Note Springer Nature remains neutral with regard to jurisdictional claims in published maps and institutional affiliations. 